\title{
Fulminant tracheobronchial aspergillosis
}

\author{
Lokendra K Thakur, ${ }^{1}$ Kunal Kishor Jha, ${ }^{1}$ Sweta Jha, ${ }^{2}$ Ambrish Jha ${ }^{3}$
}

${ }^{1}$ Department of Critical Care Medicine, Geisinger Medical Center, Danville, Pennsylvania, USA

${ }^{2}$ New York Medical College, Valhalla, New York, USA

${ }^{3}$ Rhode Island Hospital, Center for International Health Research, Providence, Rhode Island, USA

\section{Correspondence to}

Dr Kunal Kishor Jha,

kunaljhamd@gmail.com

Accepted 3 March 2017

\section{DESCRIPTION}

A man aged 56 years with a history of HIV and diffuse B-cell lymphoma (in remission) was referred to our institute for management of pancytopenia and acute kidney injury. Five days prior to the admission, the patient went to a dental clinic for tooth extraction; he was noted to have a rash on the lateral aspect of his tongue, extending through the oral cavity. On examination, he was alert, awake and oriented to time, place and person. Laboratory investigation revealed $\mathrm{Hb}: 8.3 \mathrm{mg} / \mathrm{dL}$, WCC: 500 cells $/ \mathrm{mL}$ and platelet: 70000 cells $/ \mathrm{mL}$.

BUN/Cr was 47/3, CD4 count was 350 and HIV viral load was $10 \mathrm{~K}$. Chest X-ray was unremarkable; CT scan chest revealed mediastinal lymphadenopathy. Bronchoscopy was scheduled for the evaluation of lymphoma reoccurrence. It revealed yellowish raised lesion throughout the distal trachea, right middle stream bronchus, left middle stream bronchus, right upper lobe bronchus and right lower lobe bronchus mucosa (figure 1). Rapid evaluation of bronchial biopsy revealed fungal hyphae suggestive of aspergillosis. Voriconazole was added to the treatment regimen. Next day, the patient developed shortness of breath and was intubated due to acute respiratory failure. Owing to increased peak airway pressure, it was progressively difficult to ventilate the patient. Repeat bronchoscopy on the third day revealed fungating lesion throughout trachea to the carina, which was obstructing his airways (figure 1). Bronchoalveolar lavage and bronchial biopsy was sent for cytology, bacterial, AFB, PCP and fungal evaluation. Despite aggressive respiratory support and mechanical ventilation, the patient rapidly deteriorated and died of respiratory failure.

Invasive pulmonary aspergillosis (IPA) is a lifethreatening disease that occurs in critically ill patients as well as in immunocompromised individuals. Major risk factors include neutropenia ( $<500$ cells), prolonged corticosteroid therapy, solid organ transplantation, haematological malignancy and advanced AIDS. ${ }^{1}$ Tracheobronchial aspergillosis (TBA) is a variant of IPA. TBA is associated with solitary invasion of tracheobronchial tree and most of the times, it imitates bronchopneumonia. It has non-specific symptoms such as cough, dyspnoea, sputum production and fever non-responsive to antibiotics. Although IPA is uncommon in AIDS patients, especially those on highly active antiretroviral therapy, there is increased incidence of TBA in such patients. ${ }^{2}$ It was found most of them had CD $4<100$ cells, with other factors including neutropenia and chronic corticosteroid therapy. ${ }^{2}$ Isolation of aspergillus from tracheobronchial secretion has poor predictive value, thereby, for confirmation of diagnosis, histopathological analysis is performed. ${ }^{2}$ Characteristic fibre-optic bronchoscopy findings pooled with microbiological analysis of tracheobronchial specimen obtained during bronchoscopy can accelerate the diagnostic process. Voriconazole is the drug of choice in a patient with IPA. ${ }^{3}$ If there is clinical or microscopic suspicion of TBA, medications must be instituted at the earliest.
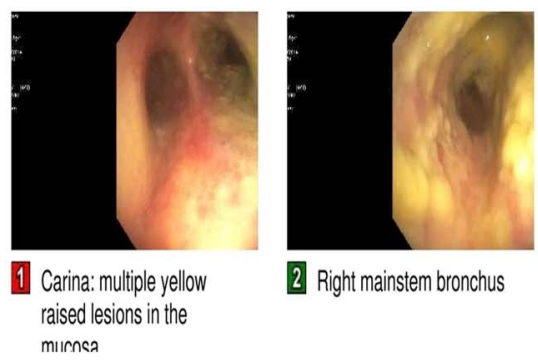

2 Right mainstem bronchus mırnsa
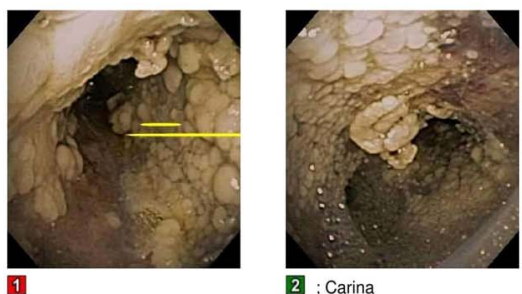

2 ; Carina

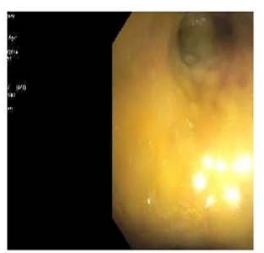

3 Bronchus intermedius

Day 1

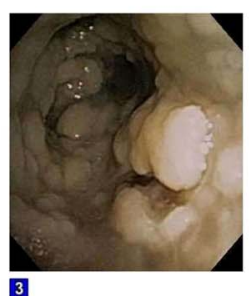

Day 3

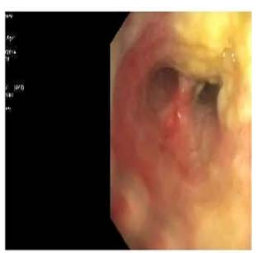

(4) Right Lower Lobe

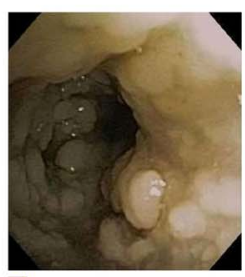

[4] ; Bronchus intermedius
To cite: Thakur LK, Jha KK, Jha S, et al. BMJ Case Rep Published online: [please include Day Month Year] doi:10.1136/bcr-2016219127
Figure 1 Bronchoscopy images on the first day revealed yellowish raised lesion throughout the distal trachea, right middle stream bronchus, left middle stream bronchus, right upper lobe bronchus and right lower lobe bronchus mucosa. On the third day, it revealed fungating lesion throughout the trachea to the carina, which was obstructing the lumen. 


\section{Learning points}

- Invasive pulmonary aspergillosis (IPA) is a life-threatening disease that occurs in critically ill patients as well as in immunocompromised individuals.

- Tracheobronchial aspergillosis (TBA) is a variant of IPA. It is associated with solitary invasion of tracheobronchial tree and most of the times, it imitates bronchopneumonia.

- Voriconazole is the drug of choice for TBA. If there is clinical or microscopic suspicion of TBA, medications must be instituted at the earliest.
Contributors LKT and KKJ assembled the case history and investigations from hospital records, analysed the data and wrote the paper. SJ and AJ selected the case, assessed the patient data and critically reviewed the paper.

Competing interests None declared.

Patient consent Obtained.

Provenance and peer review Not commissioned; externally peer reviewed.

\section{REFERENCES}

1 Soubani AO, Chandrasekar PH. The clinical spectrum of pulmonary aspergillosis. Chest 2002;121:1988-99.

2 Mylonakis E, Barlam TF, Flanigan T, et al. Pulmonary aspergillosis and invasive disease in AIDS: review of 342 cases. Chest 1998;114:251-62.

3 Sambatakou $\mathrm{H}$, Dupont $\mathrm{B}$, Lode $\mathrm{H}$, et al. Voriconazole treatment for subacute invasive and chronic pulmonary aspergillosis. Am J Med 2006;119:527.e17-24.

Copyright 2017 BMJ Publishing Group. All rights reserved. For permission to reuse any of this content visit

http://group.bmj.com/group/rights-licensing/permissions.

BMJ Case Report Fellows may re-use this article for personal use and teaching without any further permission.

Become a Fellow of BMJ Case Reports today and you can:

- Submit as many cases as you like

- Enjoy fast sympathetic peer review and rapid publication of accepted articles

- Access all the published articles

- Re-use any of the published material for personal use and teaching without further permission

For information on Institutional Fellowships contact consortiasales@bmjgroup.com

Visit casereports.bmj.com for more articles like this and to become a Fellow 